\title{
Support trees in vanilla agroforests of Madagascar: diversity, composition and origin
}

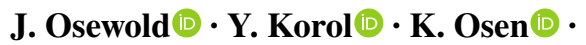 \\ M. R. Soazafy ${ }^{\circledR} \cdot$ T. Rabemanantsoa \\ D. A. Martin $\sqrt{ }$ - A. Wurz • D. Hölscher
}

Received: 26 July 2021 / Accepted: 18 January 2022 / Published online: 11 February 2022

(C) The Author(s) 2022, corrected publication 2022

\begin{abstract}
Trees in agroforestry systems provide multiple ecological and economic functions. Smallholder vanilla agroforests include shade trees common across agroforestry systems, and small-statured support trees carrying the vanilla vine. Support trees have received little scientific attention so far. The objectives of our study were to assess the diversity, composition and geographic origin of support trees in vanilla agroforestry systems of north-eastern Madagascar. The region is a global biodiversity hotspot, has been undergoing a rapid land-use change and produces a large share of the globally traded vanilla spice. The studied vanilla agroforests differed in
\end{abstract}

Supplementary Information The online version contains supplementary material available at https://doi. org/10.1007/s10457-022-00733-y.

J. Osewold and Y. Korol are Shared first authorship

J. Osewold · Y. Korol $(\bowtie) \cdot$ K. Osen · M. R. Soazafy ·

D. Hölscher

Tropical Silviculture and Forest Ecology, University

of Göttingen, Büsgenweg 1, 37077 Göttingen, Germany

e-mail: yevgeniya.korol@uni-goettingen.de

M. R. Soazafy

Doctoral School of Natural Ecosystems (EDEN),

University of Mahajanga, Mahajanga, Madagascar

M. R. Soazafy

Natural and Environmental Sciences, Regional University

Centre of the SAVA Region (CURSA), Antalaha,

Madagascar land-use history: established either directly inside forest (forest-derived) or on land previously used for slash-and-burn agriculture (fallow-derived). Among the support trees, we found 122 species of which $25 \%$ were endemic to Madagascar. The species richness per plot was four times higher in forest-derived than in fallow-derived vanilla agroforests. The species distribution was particularly uneven in fallow-derived vanilla agroforests with one species (Jatropha curcas) comprising $52 \%$ of all individuals. In forest-derived vanilla agroforests, $44 \%$ of all trees were native or endemic to Madagascar, whereas in fallow-derived vanilla agroforests only $11 \%$ were native or endemic. We conclude that there is a considerable diversity among support trees in Malagasy vanilla agroforestry. The support tree diversity is strongly affected by landuse history. Fallow-derived vanilla agroforests currently have a comparatively low species richness, yet

\section{T. Rabemanantsoa \\ Diversity Turn Research Project, Sambava, Madagascar \\ D. A. Martin \\ Biodiversity, Macroecology and Biogeography, University of Goettingen, Büsgenweg 1, 37077 Göttingen, Germany}

D. A. Martin

Wyss Academy for Nature, University of Bern, Kochergasse 4, 3011 Bern, Switzerland

A. Wurz

Agroecology, University of Goettingen, Grisebachstr. 6, 37077 Göttingen, Germany 
they can play an important role in land rehabilitation, and more emphasis on growing native and endemic tree species would contribute to aligning production with conservation goals.

Keywords Biodiversity $\cdot$ Endemism $\cdot$ Land-use history $\cdot$ Native trees $\cdot$ Smallholder agroforestry . Tutor trees

\section{Introduction}

Agroforestry systems comprise trees and crops or livestock (FAO 2015). Studies often investigate multiple ecological and economic functions of shade trees (Nesper et al. 2017; Tscharntke et al. 2011) or cropbearing woody plants like apple, cherry, coffee (Kay et al. 2020; Liu et al. 2020; Wu et al. 2016). However, vanilla agroforests have a further category of trees: support trees (also called tutor trees) which are smallstatured and carry the climbing vanilla plant (Vanilla planifolia, Orchidaceae). Support trees (Fig. 1) are pruned to an accessible height to facilitate vanilla hand-pollination and vanilla harvesting. Support trees are also common in other agroforestry systems, e.g., black pepper (Piper nigrum), yams (Dioscorea spp.) or chayote (Sechium edule) (World Agroforestry Centre 2009).
Madagascar contributes about $40 \%$ of natural vanilla to the world market (FAO 2020). The island is also a biodiversity hotspot with particularly high rates of endemism (Ganzhorn et al. 2014; Myers et al. 2000). Forests of Madagascar harbour the majority of endemic plants and animal species (Dufils 2003), but large parts of natural forests have already been lost and deforestation rates are still high (Vieilledent et al. 2018). Even though some species can persist in human-modified landscapes (e.g., Raveloaritiana et al. 2021; Torppa et al. 2020) and information of responses to habitat degradation is lacking for many taxa (Irwin et al. 2010), deforestation certainly threatens Madagascar's biodiversity (Ganzhorn et al. 2001; Rakotoarinivo et al. 2014). Slash-and-burn shifting cultivation is the main driver of deforestation in Madagascar (Yesuf et al. 2019; Zaehringer et al. 2015).

Agroforests can contribute to biodiversity maintenance in deforested and degraded landscapes (Montagnini 2020; Schroth et al. 2004). Vanilla agroforests in north-eastern Madagascar support native bird species (Martin et al. 2021b), several lemur species (Hending et al. 2018) and many plant species (Osen et al. 2021; Raveloaritiana et al. 2021). The shade trees in vanilla agroforests are highly diverse and include many endemic species (Osen et al. 2021). Additionally, vanilla agroforests with many shade trees and a dense understory can contribute to the
Fig. 1 Smallholder vanilla agroforests in Madagascar with support trees for the vanilla plants. A forestderived vanilla agroforest (a) a fallow-derived vanilla agroforest (b) establishment of a new vanilla agroforest with freshly planted support trees (c) attaching a vanilla vine to a support tree (d)
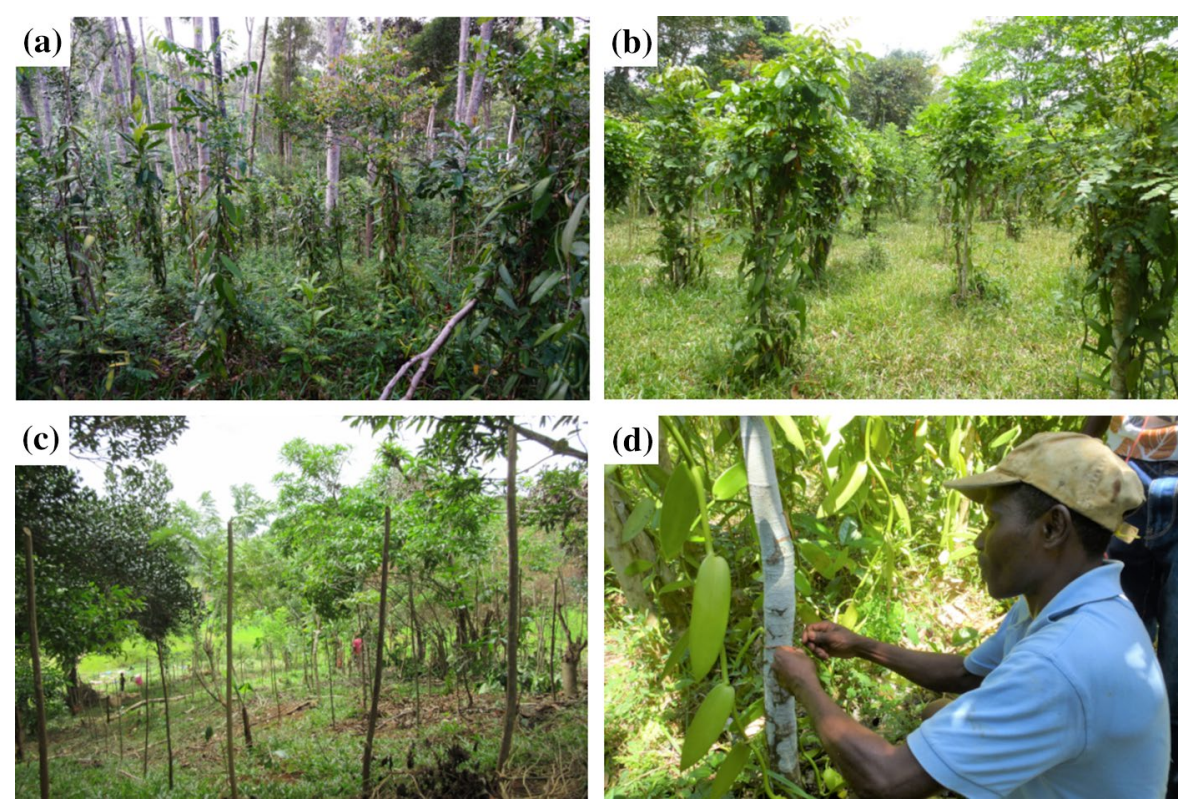
conservation of predation as an important ecosystem function (Schwab et al. 2021).

The diversity of crops and associated trees as well as the structural complexity of an agroforestry system can evolve under climatic, social and economic pressure as shown, e.g., for Malagasy clove cultivation (Michel et al. 2021). For vanilla agroforests in north-eastern Madagascar, also the previous land-use history is important. They are established either by thinning and converting forests (forest-derived vanilla agroforests) or on an open or fallow land previously used for slash-and-burn agriculture (fallow-derived vanilla agroforests). Forest-derived vanilla agroforests contribute to species preservation but are a degradation of a natural forest ecosystem; fallow-derived vanilla agroforests may harbour less biodiversity but significantly contribute to ecosystem rehabilitation (Martin et al. 2020; Osen et al. 2021; Raveloaritiana et al. 2021). Nevertheless, both types of vanilla agroforests provide considerable income opportunities to farmers and have similar vanilla yield (Martin et al. 2021a).

According to our observations, vanilla vines in the vanilla agroforestry of north-eastern Madagascar are almost exclusively put on living support trees which serve as climbing structures. Both in Madagascar and worldwide, support trees have received little scientific attention so far. However, these trees are intensively managed by farmers and thus offer the opportunity to influence the diversity and structure of agroforests. Our objectives were to identify the species diversity, composition and geographic origin of the support trees in forest-derived and fallow-derived vanilla agroforests in north-eastern Madagascar. The results may inform approaches to creating a multifunctional landscape and contribute to maintaining or restoring tree diversity in agroforestry systems.

\section{Methods}

Study region

The study was conducted in north-eastern Madagascar (Fig. 2). The regional climate is tropical-humid with an annual mean temperature of $24.1{ }^{\circ} \mathrm{C}$ and precipitation of $2157 \mathrm{~mm} \mathrm{y}^{-1}$ (means across study plots, based on CHELSA (Karger et al. 2017)). The dominating soil type is Haplic Ferralsol (ESDAC
2014). The topography consists of coastal lowlands, hills and mountains. The natural vegetation is tropical rainforest (Moat and Smith 2007), now mainly restricted to protected areas like Marojejy National Park (Vieilledent et al. 2018). The landscape is characterized by a mosaic of land-use types where slashand-burn shifting cultivation, locally called tavy, paddy rice, and vanilla agroforestry prevail (Hänke et al. 2018; Llopis et al. 2019).

\section{Sampling design}

We worked in 10 villages across north-eastern Madagascar's SAVA region (Fig. 2). In each village, we studied three vanilla agroforests. Interviews with the farmers revealed that 10 out of 30 studied vanilla agroforests were forest-derived, whereas 20 were fallow-derived and established on the land that underwent at least one cycle of slash-and-burn agriculture. The age of the forest-derived and the fallow-derived vanilla agroforests varied between 4 to 30 years and 3 to 58 years respectively (Online Resource 1 ). In every vanilla agroforest, we placed a circular study plot of $50 \mathrm{~m}$ diameter $\left(1963 \mathrm{~m}^{2}\right)$. We put 36 markings in a fixed scheme (Fig. 3) inside the plots. At each marking, we sampled the support tree carrying a living vanilla plant that grew closest to the respective marking. On every study plot, our selection of 36 support trees represented a share of 3-11\% of all support trees within the study plot, depending on the vanilla planting density. Overall, we sampled 1080 support trees consisting of 68 dead and 1012 living support trees. For our analysis, we only considered the 1012 living support trees (Online Resource 1).

\section{Species identification}

In the field, we identified 960 of 1012 sampled living support trees to their vernacular names. We took samples and photos (mostly leaves, bark and branches, rarely flowers or fruits) and consulted a botanist from Madagascar National Parcs to identify the remaining 52 support trees to their vernacular names. Thereafter, we used Schatz et al. (2001) and assigned the vernacular names to the corresponding scientific names for 86 species making up 305 trees in our sample. Although Schatz et al. (2001) only differentiates species to genus level, some genera are monotypic and thus a species name could be 


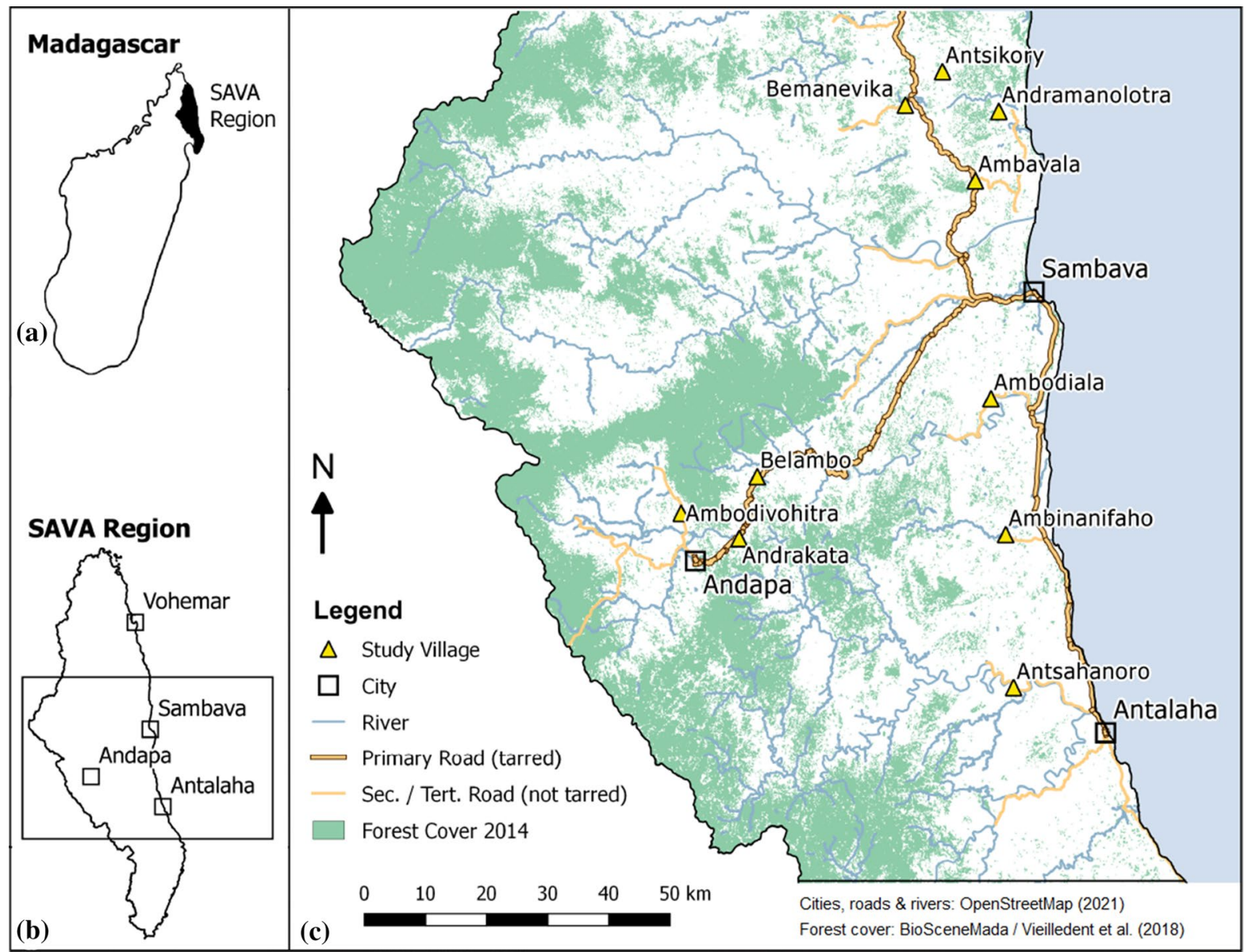

Fig. 2 Location of the SAVA region in Madagascar (a) location of our study region within the SAVA region (b) a close-up of the study region with the study villages (yellow triangles) (c)

assigned. If a vernacular name corresponded to several genera, we requested support by a tree expert from Missouri Botanical Garden Antananarivo to decide for one of them. In addition, we used a report on the floral inventory of the Antanetiambo Nature Reserve (Randrianaivo 2014) and an unpublished inventory list from 2001 provided by Marojejy National Park staff to get suggestions of scientific names matching the vernacular names. The suggestions were then validated by the descriptions of tree characteristics in Schatz et al. (2001). In doubtful cases and in the cases not covered by Schatz et al. (2001), we used a species list by Osen et al. (2021) for verification (63 species, 223 trees in our sample). Finally, we could identify $41 \%$ of species in our sample ( $86 \%$ of all sampled tree individuals) to scientific species names; $51 \%$ species $(11 \%$ of all individuals) to genus level and $8 \%$ of species (3\% of all individuals) to their vernacular names (Online Resource 2). However, some uncertainties remain. These are partly due to the frequent taxonomic rearrangements of the diverse Malagasy tree flora (Callmander et al. 2011) which can be challenging to align with local vernacular naming systems. Additionally, tree identification is often based on reproductive features, so sterile and/or young tree individuals can hamper identification precision (Gomes et al. 2013). Support trees in vanilla agroforests often lack reproductive features, as they are removed during pruning. Therefore, we acknowledge that taxonomic uncertainties might underestimate the diversity of rare species in our support tree assessment. 


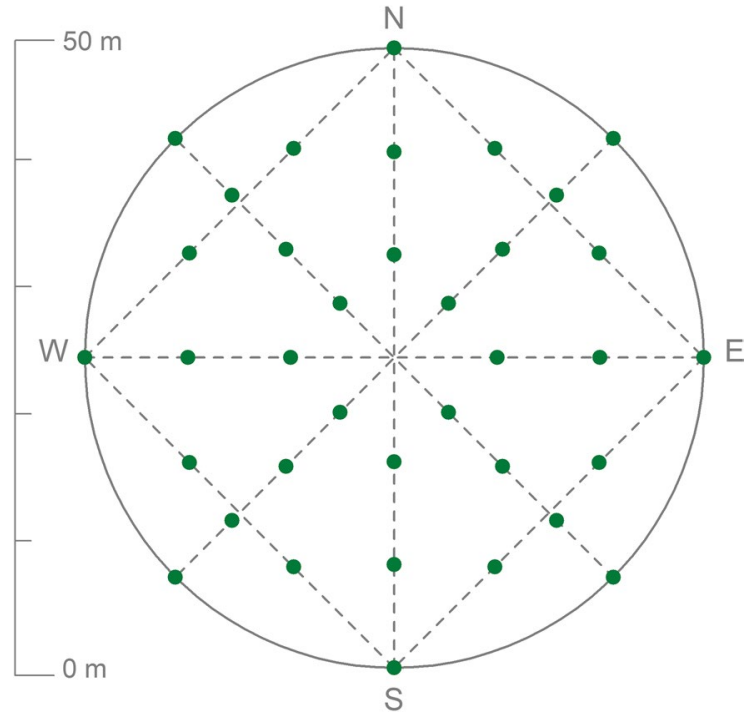

Fig. 3 Support tree sampling scheme within a circular study plot (50 m diameter) in each of the 30 vanilla agroforests. The dashed lines represent the grid of ropes used to set the scheme. The green dots $(n=36)$ represent the markings along the ropes to select the closest growing support tree

\section{Species origin and diversity}

Using the Catalogue of the Plants of Madagascar by Tropicos (2021) and GlobalTreeSearch (2021), we categorized the support tree species based on their origin into endemic (existing naturally only in Madagascar), native (existing naturally in Madagascar but also in other places) or introduced (do not exist in Madagascar naturally). The categorization was possible for all trees identified to species level (882 from 1012 trees in the total sample). We further assessed the global conservation status of the species using the IUCN Red List (IUCN 2021) and The Red List of Trees of Madagascar (Beech et al. 2021). Diversity was calculated as species richness (species per plot) and Shannon index (Shannon 1949). We further calculated the Jaccard index as a complementary descriptor for similarities between forest-derived and fallow-derived vanilla agroforests (Jaccard 1902). Additionally, we calculated relative frequency and the importance index of support tree species (Aryal et al. 2019). We included all species and morphospecies (identification to genus level or vernacular names) into the diversity analysis.
Tree structure

We measured the diameter of each support tree in our sample at the height of $50 \mathrm{~cm}$. If a tree had more than one trunk, we selected the thickest one. We also measured the height of the support trees. Additionally, we measured the crown diameter of the support trees along the cardinal directions (north-south, west-east) and calculated the mean of both crown measurements for each support tree.

Interviews

We conducted interviews to assess the share of planted support trees and to clarify what kind of secondary products support trees currently provide. For each vanilla agroforest, we interviewed the person directly involved in its management, resulting in 30 interviews, equalling one interview per agroforest. Within each interview, our questions addressed the planting management and use per support tree species. If several support tree individuals belonged to the same species, we grouped them within the respective agroforest. In this way, we obtained data on $92 \%$ of all support tree individuals in our sample. For $8 \%$ of support tree individuals (mainly of singletons), we could not match interview data. Answer categories in the interviews were provided for each question as well as a possibility to give a free answer (answer category "other"). We conducted every interview only after an explicit informed consent given by each interviewee verbally. All interview participants were free to skip questions and had the right to stop the interview any time.

\section{Statistics}

We checked all data for the normality of distribution with the Shapiro-Wilk test (Shapiro and Wilk 1965). We applied the unpaired t-tests (Welch 1947) to analyse the differences between forest-derived and fallow-derived vanilla agroforests in both the species richness per plot and Shannon index. We calculated the share of endemic, native and introduced species per plot and used the Mann-Whitney-U-Test (Mann and Whitney 1947) to test for significant differences between forest-derived and fallow-derived vanilla agroforests. We also applied the Mann-WhitneyU-Test to test for the differences in tree diameter, 
height and crown diameter. Additionally, we used the Mann-Whitney-U-Test to test for the difference of the share of planted support trees between forest- and fallow-derived vanilla agroforests. Statistically significant difference was assumed at $\mathrm{p}<0.05$. We performed the statistical analysis in $\mathrm{R}$ version 4.0.2 ( $\mathrm{R}$ Core Team 2013) and calculated the Shannon index with the R packages "vegan" (Oksanen et al. 2019). We also used packages "plotrix" (Lemon 2006) and "VennDiagram" (Chen 2018) for visualization purposes. Furthermore, we used the interview data to calculate secondary use values per individual and per species.

\section{Results}

Species diversity and abundance

In total, we found 122 support trees species belonging to 84 genera and 38 families (Online Resource 2). The number of species supported by forest-derived vanilla agroforests (115 species) was higher than in fallow-derived vanilla agroforests (31 species; Fig. 4). The species richness per plot was significantly higher in the forest-derived vanilla agroforests $($ mean $=19.7$, $\mathrm{sd}=7.3$ ) than in the fallow-derived vanilla agroforests $($ mean $=4.4, \mathrm{sd}=2.1)$, unpaired $\mathrm{t}$-test, $\mathrm{t}=6.54$, $\mathrm{df}=9.75, p<0.001$ (Table 1 ). The diversity of support trees indicated by the Shannon index was, again, significantly higher for forest-derived vanilla agroforests $($ mean $=2.6, \mathrm{sd}=0.65)$ than for fallow-derived vanilla agroforests $($ mean $=0.83, \mathrm{sd}=0.56)$, unpaired

\section{All species}

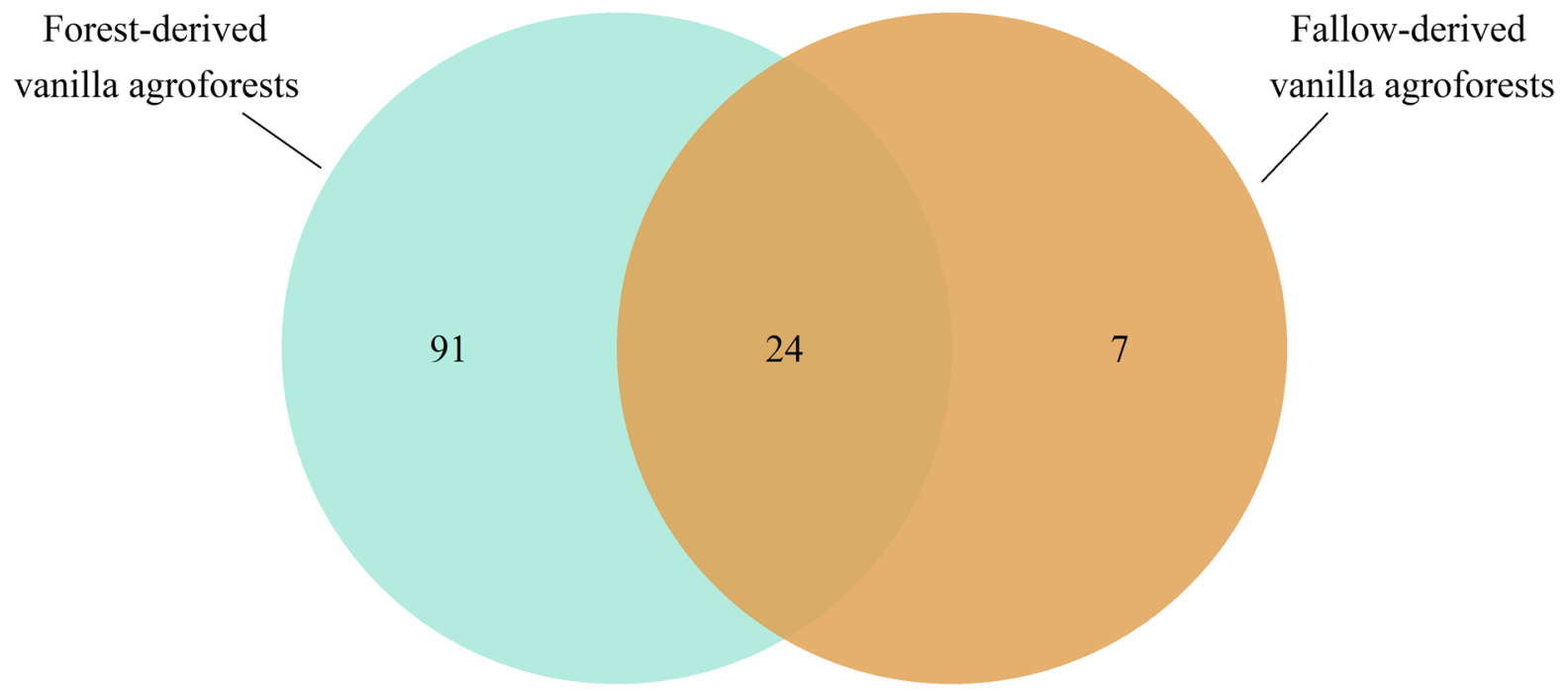

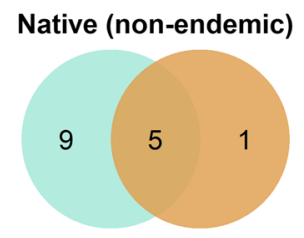

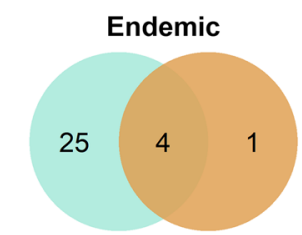

Fig. 4 Number of support tree species being different (circle margins) or common (circle intersections) for 10 forest-derived and 20 fallow-derived vanilla agroforests in the study region. The bottom part of the diagram displays the total numbers

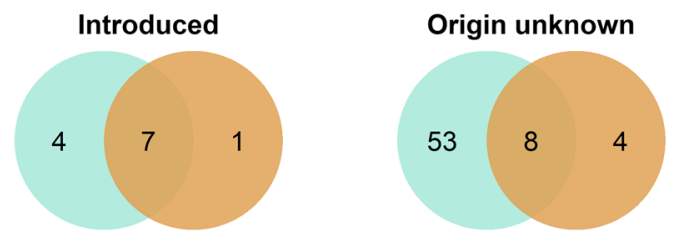

according to the origin (native, endemic and introduced) of the species. Origin of the species identified to genus or vernacular names only could not be specified (Origin unknown) 
Table 1 Species diversity of support trees in forest-derived $(n=10)$ and fallow-derived $(n=20)$ vanilla agroforests in north-eastern Madagascar

$\begin{array}{llllll}\text { All vanilla agroforests } & \begin{array}{l}\text { Forest-derived } \\ \text { vanilla agroforests }\end{array} & \begin{array}{l}\text { Fallow-derived } \\ \text { vanilla agroforests }\end{array} & \begin{array}{l}\text { t-value } \\ \text { (unpaired } \\ \text { t-test) }\end{array} & \text { df } & p \text {-value }\end{array}$

\begin{tabular}{|c|c|c|c|c|c|c|}
\hline Species richness (n, total) & 122 & 115 & 31 & & & \\
\hline \multicolumn{7}{|l|}{ Species richness (n per plot) } \\
\hline Mean (SD) & $9.5(8.6)$ & $19.7(7.3)$ & $4.4(2.1)$ & 6.54 & 9.75 & $<0.001$ \\
\hline $\operatorname{Min}-\max$ & $1-29$ & $6-29$ & $1-8$ & & & \\
\hline \multicolumn{7}{|l|}{ Shannon index } \\
\hline Mean (SD) & $1.42(1.03)$ & $2.6(0.65)$ & $0.83(0.56)$ & 7.32 & 15.96 & $<0.001$ \\
\hline Min - max (per plot) & $0.00-3.34$ & $1.19-3.34$ & $0.00-1.84$ & & & \\
\hline
\end{tabular}

t-test, $\mathrm{t}=7.32, \mathrm{df}=15.96, p<0.001$ (Table 1). The Jaccard index for all support tree species in forestderived and fallow-derived agroforests was 0.24 . The index was 0.5 for the native, non-endemic species. It was 0.15 for the endemic species and 1.4 for the introduced species (see also Fig. 4).

The three most abundant species comprising 53\% of all sampled trees were Jatropha curcas, Clausena excavata and Pachira glabra. J. curcas dominated our sample also in terms of the relative frequency and the Importance index (Online Resource 2). In forest-derived vanilla agroforests, the most abundant $15 \%$ of species, i.e. 16 species, contributed $50 \%$ of all trees. Other $38 \%$ of species in our sample for forestderived vanilla agroforests were represented by $2-4$ individuals and $47 \%$ by only 1 individual each. The tendency of some species being highly abundant and many being rare was even more pronounced in the fallow-derived vanilla agroforests where just one species (Jatropha curcas) accounted for $52 \%$ of all support trees (Fig. 5).

\section{Species origin and IUCN status}

We found 45 out of 122 species to be native or endemic (12\% of all species native, non-endemic and $25 \%$ of all species endemic; see also Fig. 4). Among them, 11 were endemic at genus level. We observed 12 introduced species which accounted for two-thirds of all sampled trees (Fig. 6). The summed share of native and endemic species among all found species was similar for the forest-derived and fallow-derived vanilla agroforests $(37 \%$ and $35 \%$ of species, see also Fig. 4). Nevertheless, the situation differed when accounting for support trees abundances: $44 \%$ of all individuals in the forest-derived vanilla agroforests belonged to the native or endemic flora, whereas only $11 \%$ of the individuals were native or endemic in fallow-derived vanilla agroforests (Fig. 6).

Among all 50 species that we could identify to species level, $82 \%$ have been assessed in the IUCN Red List (IUCN 2021). Most of the species had the status "LC - Least Concern". Intsia bijuga was listed as vulnerable, Dichaetanthera altissima as endangered. Both species formed $0.5 \%$ of the whole sample and were only encountered in the forest-derived vanilla agroforests.

\section{Tree structure}

The support trees were prevailingly small-statured with the median of the stem diameter $3.7 \mathrm{~cm}$ $(\mathrm{IQR}=2.5 \mathrm{~cm})$, the median of the height $2.4 \mathrm{~m}$ $(\mathrm{IQR}=1.3 \mathrm{~m})$ and the median of the crown diameter $0.9 \mathrm{~m}(\mathrm{IQR}=0.7 \mathrm{~m})$ (Online Resource 1). No significant differences were found for the structure of support trees in forest-derived and fallow-derived vanilla agroforests (Table 2).

\section{Planted support trees}

According to our farmer interviews, $21 \%$ of all support trees in forest-derived vanilla agroforests were planted (median $=0 \%, \mathrm{IQR}=33 \%, \mathrm{n}_{\text {plots }}=10$ ). In contrast, $71 \%$ of all support trees in fallow-derived vanilla agroforests were planted (median $=83 \%, \mathrm{IQR}=27 \%$, $\mathrm{n}_{\text {plots }}=20$ ). A Mann-Whitney-U-Test indicated a significant difference between both groups $(\mathrm{U}=30$, $\mathrm{p}=0.002)$. The support trees species whose individuals were mostly planted were Jatropha curcas $(97 \%$, 
Forest-derived vanilla agroforests

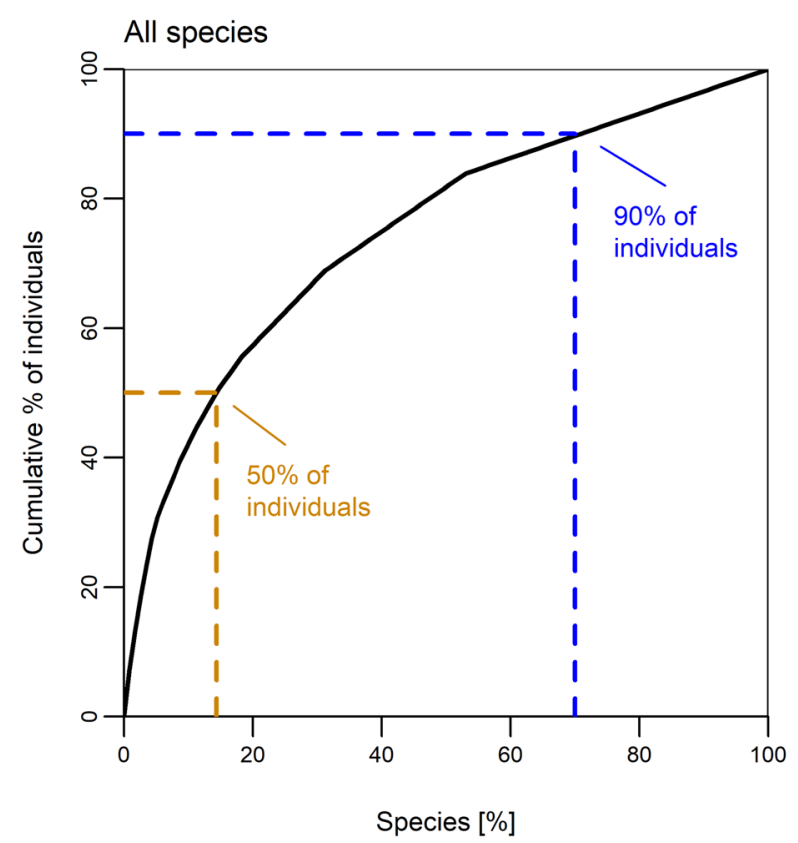

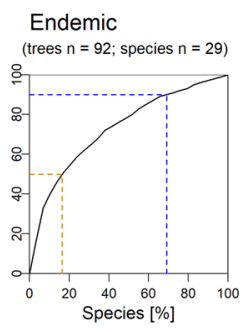

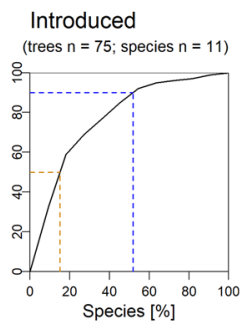

Fig. 5 Species dominance structure among support trees in forest-derived and fallow-derived vanilla agroforests. In forestderived vanilla agroforests ( $n=10$ plots), we found 115 species among 335 individuals. In fallow-derived vanilla agroforests

of all individuals planted), Pachira glabra, Gliricidia sepium and Morus alba (each with $100 \%$ individuals planted). Thus, planted trees were mostly introduced species.

Secondary use of support trees

Secondary use could be confirmed for $32 \%$ of all support trees in our sample. Most common secondary uses of support trees included personal use as medicine (12\% of all individuals) and edible fruits
Fallow-derived vanilla agroforests
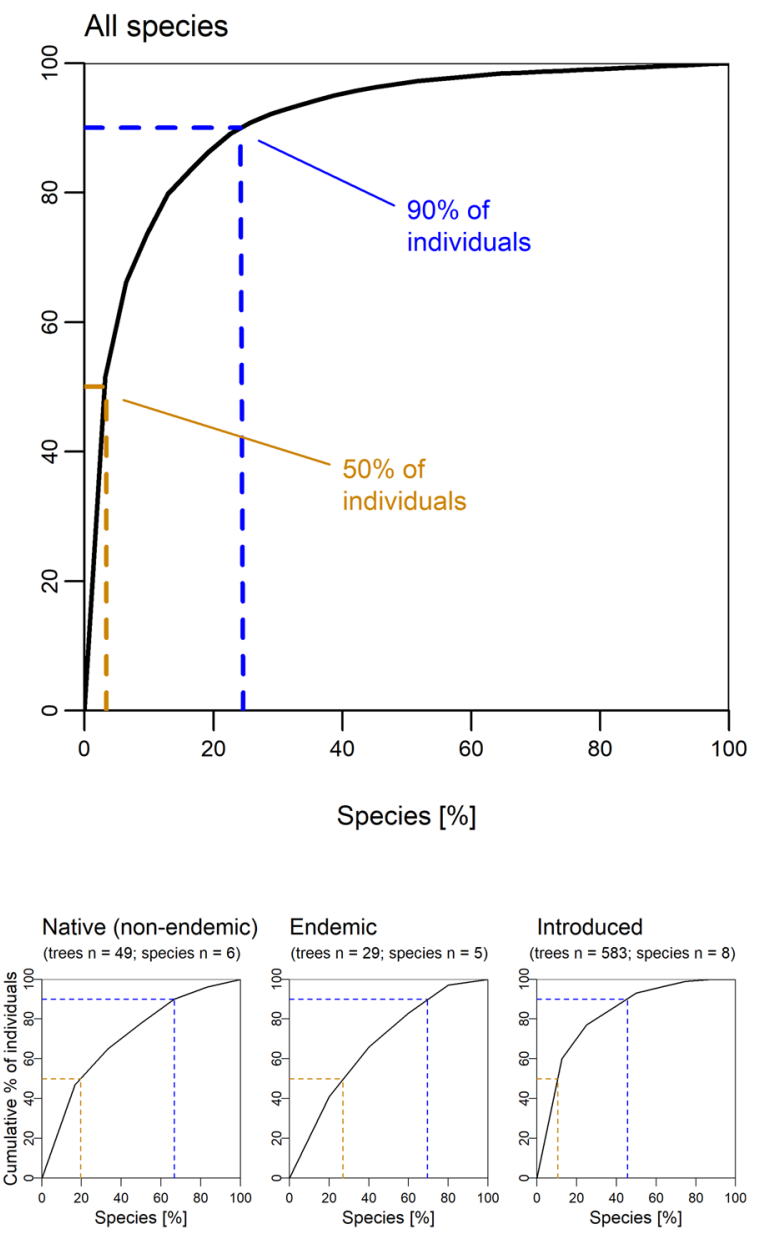

( $n=20$ plots), there were 31 species among 677 individuals. The brown dashed line indicates the share of species contributing $50 \%$ of all individuals; the blue dashed line indicates the share of species contributing $90 \%$ of all individuals

for personal consumption or selling (6\% of all individuals). Among the introduced species, the most used ones were Coffea canephora ( $81 \%$ of individuals for personal consumption as food; $54 \%$ for selling food; and 12\% each for medicine and firewood), Jatropha curcas (20\% of individuals used for medicine) and Morus alba (92\% of all individuals used for medicine). Among native species, the most used one was Parinari curatellifolia (18\% of individuals used for food and $18 \%$ for medicine). Another relatively frequently used native species was Sorindeia madagascariensis (28\% of individuals used for personal food consumption). 
All vanilla agroforests

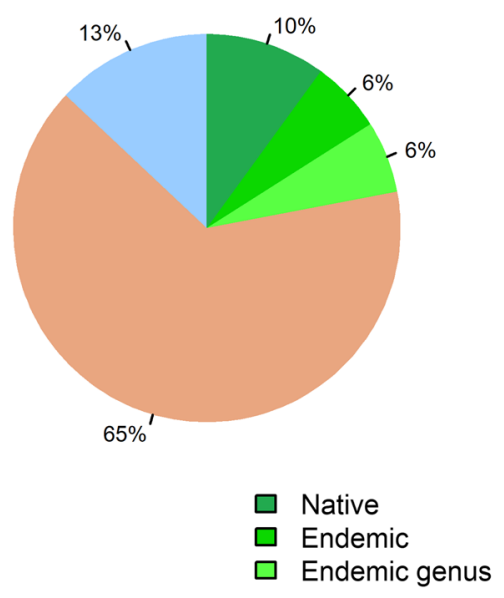

Forest-derived vanilla agroforests

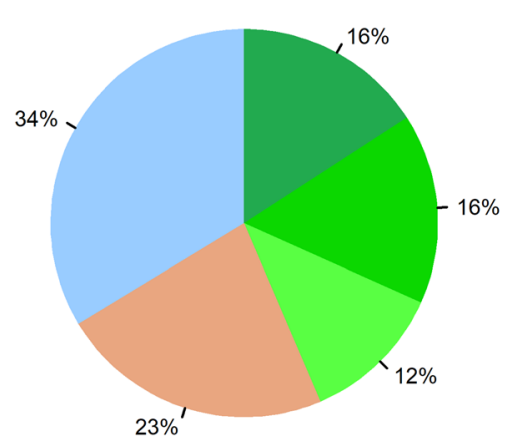

$\square \quad$ Introduced

$\square$ Origin unknown
Fallow-derived vanilla agroforests

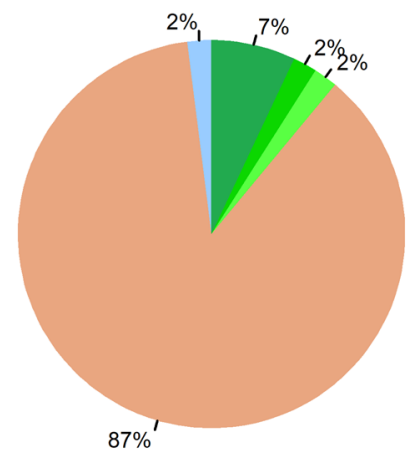

Fig. 6 Share of tree individuals belonging to native, endemic or introduced species across all vanilla agroforests $(n=30)$, in forest-derived ( $\mathrm{n}=10$ plots) and in fallow-derived $(\mathrm{n}=20$ plots) vanilla agroforests. We could not specify the origin of the species defined to genus or vernacular names only (Origin unknown). The share of trees belonging to introduced species differed significantly between forest-derived (median $=6 \%$, $\mathrm{IQR}=37 \%)$ and fallow-derived (median $=93 \%, \mathrm{IQR}=11 \%)$ vanilla agroforests, Mann-Whitney-U-Test, $\mathrm{U}=183.5 ; p<$ 0.001

Table 2 Structure characteristics of support trees in forest-derived ( $\mathrm{n}$ trees $=335)$ and fallow-derived $(\mathrm{n}$ trees $=677)$ vanilla agroforests in north-eastern Madagascar

\begin{tabular}{lllll}
\hline & $\begin{array}{l}\text { All vanilla agro- } \\
\text { forests }\end{array}$ & $\begin{array}{l}\text { Forest-derived vanilla } \\
\text { agroforests }\end{array}$ & $\begin{array}{l}\text { Fallow-derived vanilla } \\
\text { agroforests }\end{array}$ & $\begin{array}{l}\text { U-value (Mann-Whit- } p \text {-value } \\
\text { ney-U-test) }\end{array}$ \\
\hline $\begin{array}{l}\text { Stem diameter }(\mathrm{cm}) \\
\text { Median }\end{array}$ & 3.7 & 3.5 & 3.8 & 118,102 \\
$0.05-0.95$ quantiles & $1.9-8.1$ & $2.0-9.1$ & $1.8-7.8$ & 0.28 \\
Tree height (m) & & & 2.4 & 105,934 \\
Median & 2.4 & 2.5 & $1.5-5.0$ & 0.08 \\
$0.05-0.95$ quantiles & $1.4-4.9$ & $1.4-4.7$ & & 115,552 \\
Crown diameter (m) & & & 0.95 & 0.59 \\
Median & 0.9 & 0.9 & $0.3-2.2$ & \\
$0.05-0.95$ quantiles & $0.3-2.4$ & $0.4-2.3$ & & \\
\hline
\end{tabular}

\section{Discussion}

In vanilla agroforests of north-eastern Madagascar, we found 122 species of support trees used for carrying vanilla plants. Land-use history strongly influenced the species richness with higher diversity in forest- than in fallow-derived vanilla agroforests. Species abundance was highly uneven with few dominant and many rare species, especially in fallow-derived vanilla agroforests. Endemic species dominated the group of native species (30 of 45 native species).
Together, native and endemic species comprised $44 \%$ of the support trees in forest- and $11 \%$ in fallowderived vanilla agroforests. The most abundant support tree species was Jatropha curcas, an introduced species.

Species richness of support trees compared with shade trees

The total of 122 support tree species is lower than 229 species of shade trees encountered on the same 
plots (all sampled shade trees $>8 \mathrm{~cm}$ dbh; Osen et al. 2021). While most support tree species identified to the species level were also found among shade trees, $18 \%$ (i.e. 9 of 50) were not. Four of these (Hibiscus tiliaceus, Manihot esculenta, Psiadia altissima and Tambourissa thouvenotii) are shrubs or small trees and thus less likely to be accounted for in shade tree surveys. However, except M. esculenta, these species are native to Madagascar and two of them $(P$. altissima and T. thouvenotii) belong to the endemic Malagasy flora. Overall, six of the support tree species without shade trees analogous have the status of endemics. We found seven of the support species without shade trees analogous exceptionally in the forest-derived vanilla agroforests and two other species (H. tiliaceus and P. altissima) only in the fallowderived vanilla agroforests. The difference between support and shade tree species indicates that support trees enrich the overall native and endemic plant diversity in vanilla agroforests of the region.

Land-use history determines support tree diversity

Our data suggest that land use history strongly influences species richness of support trees in vanilla agroforests of north-eastern Madagascar. Forestderived vanilla agroforests show a higher species richness (with a mean of 19.7 species per plot) than fallow-derived vanilla agroforests (with a mean of 4.4 species per plot). This corresponds to a similar trend in tree species diversity among shade trees (Osen et al. 2021). This is also in line with the analyses by Martin et al. (2020) emphasizing the importance of land-use history for biodiversity and ecosystem services in agroforestry systems. Overall, with 122 species of support trees and 229 species among shade trees (Osen et al. 2021), the vanilla agroforests in north-eastern Madagascar contribute to maintaining the unique tree diversity of the island.

Support tree management results in strong unevenness in species abundances

Our findings revealed a strong unevenness in the abundance of support tree species (Fig. 5): few species were highly abundant, and many species were rare. In fallow-derived vanilla agroforests, just one species (Jatropha curcas) accounted for 52\% of all trees. J. curcas and other introduced species abundant in the fallow-derived vanilla agroforests like Gliricidia sepium, Pachira glabra and Morus alba were mostly planted. Planting G. sepium and J. curcas, farmers in north-eastern Madagascar possibly follow guidelines of a former extension and training project that recommended to use these species (J.-J. Tsialefitra, personal communication, 12.12.2016). Planting these introduced species may be motivated by their easy propagation by cuttings as well as nitrogen fixing abilities (World Agroforestry Centre 2009). J. curcas and $G$. sepium, both being native for Mesoamerica and Mexico, are known for these characteristics and used as support structures for vanilla in Africa, Asia and Oceania (Hernandez and Lubinsky 2011; Komarek 2010; Minh et al. 2015; Van der Grijp 1997). G. sepium is also used as support structure for other crops as black pepper and yam in West Africa and India (World Agroforestry Centre 2009). Introduced trees can contribute to people's livelihood (Gérard et al. 2015; Kull et al. 2013), and the introduced J. curcas and M. alba were used for medicinal purposes in our study region. However, G. sepium and $P$. glabra, the two other frequently planted introduced species, had no such use. On the other hand, some native species like Parinari curatellifolia and Sorindeia madagascariensis were used for food and medicine at rates comparable with that of J. curcas.

Promoting native and endemic support trees to foster ecosystem service provisioning

In total, in our sampled vanilla agroforests, introduced species hold a low share of species $(11 \%)$ but a relatively high share of all individuals (65\%). One of them, J. curcas, was classified as invasive by Kull et al. (2012). However, our impression is that this consideration would need further assessment in the mosaic landscape of north-eastern Madagascar. Furthermore, our data suggest that also many native or endemic species can be used as support tree species as particularly found in forest-derived vanilla agroforests. Also, in cardamom (Aframomum angstifolium) and long pepper (Piper capense) agroforestry in south-western Ethiopia farmers use native tree species (Furo et al. 2020). There, farmers take advantage from the knowledge of traits that make a species a suitable shade or support tree (Furo et al. 2020). At least 45 support tree species encountered in our sample were native to Madagascar of which 30 
were endemic including 11 being endemic at genus level. This might be a potential for vanilla farming that favours native and endemic tree diversity. Promoting native and endemic support tree species can contribute to maintaining other native and endemic taxa as far as small-statured trees can also provide habitat and food for associated fauna in human-modified landscapes, especially if such trees are present in large quantities (Le Roux et al. 2015). Being a part of the understory, they could also help to support high predation rates as described by Schwab et al. (2021).

\section{Conclusion}

Overall, we conclude that vanilla agroforests in northeastern Madagascar are rich in tree species, including the support trees. Native and endemic tree species are being used for carrying the vanilla plants with particularly many native and endemic species observed in forest-derived vanilla agroforests. The relatively high number of native and endemic species in forestderived vanilla agroforests as well as a high share of support tree individuals belonging to these species groups, imply a considerable conservation value of forest-derived vanilla agroforests. On the other hand, since fallow-derived vanilla agroforests can play an important role in restoration and rehabilitation but are today largely dominated by introduced species among support trees, we suggest a stronger consideration of native or even endemic tree species also in the establishment of new vanilla agroforests.

Acknowledgements We are thankful to agroforest owners, chef de fokontany (village authorities) and the village communities for receiving us and providing us access to their vanilla agroforests. Special thanks to the local tree specialist Jean Chrysostome Bevao from Madagascar National Parcs (MNP) and the tree expert Patrice Antilahimena from Missouri Botanical Garden Antananarivo, for supporting us with the tree species identification. We collected data under the research permit $\mathrm{N}^{\circ} 18 / 18 / \mathrm{MEEF} / \mathrm{SG} / \mathrm{DGF} / \mathrm{DSAP} / \mathrm{SCB}$.Re granted by the Ministry for Water, Ecology and Forest (MEEF), Antananarivo, Madagascar. We thank MNP and MEEF for the collaboration. Our work was financially supported by the 'Niedersächsisches Vorab' of 'Volkswagen Foundation' as part of the research project 'Diversity Turn in Land Use Science' (Grant number 11-76251-99-35/13 (ZN3119)). MRS was supported by the German Academic Exchange Service (DAAD) within the 'Partnerships for Supporting Biodiversity in Developing Countries' initiative (Project Nr. 57449386).
Author's contributions JO, KO, AW, DAM, MRS and DH conceived the ideas and designed methodology; JO and TR collected the data; JO processed and analysed the data; YK, JO $\&$ DH led the writing of the manuscript. All authors contributed to the manuscript and gave final approval for publication.

Funding Open Access funding enabled and organized by Projekt DEAL. Our work was financially supported by the 'Niedersächsisches Vorab' of 'Volkswagen Foundation' as part of the research project 'Diversity Turn in Land Use Science' (Grant number 11-76251-99-35/13 (ZN3119)). MRS was supported by the German Academic Exchange Service (DAAD) within the 'Partnerships for Supporting Biodiversity in Developing Countries' initiative (Project Nr. 57449386).

Availability of data and material The raw data of the study are available at the Open Science Framework: https://doi.org/ 10.17605/OSF.IO/742JW.

\section{Declarations}

Conflict of interest The authors of the submitted manuscript declare that they have neither financial nor non-financial conflicts of interest relevant for the content of the article.

Consent to participate The owners of the studied agroforests provided us access to their land. They were free to deny the access and/or stop the process of sampling. Also, an interview with agroforest owners was a part of our study. Before the interview, interviewees gave their participation agreement verbally. They were free to refuse or withdraw their answers. They also were aware that it was possible to stop the interview any time.

Consent for publication All agroforest owners and interview participants gave their verbal approval for the results of our study to be published.

Open Access This article is licensed under a Creative Commons Attribution 4.0 International License, which permits use, sharing, adaptation, distribution and reproduction in any medium or format, as long as you give appropriate credit to the original author(s) and the source, provide a link to the Creative Commons licence, and indicate if changes were made. The images or other third party material in this article are included in the article's Creative Commons licence, unless indicated otherwise in a credit line to the material. If material is not included in the article's Creative Commons licence and your intended use is not permitted by statutory regulation or exceeds the permitted use, you will need to obtain permission directly from the copyright holder. To view a copy of this licence, visit http://creativecommons.org/licenses/by/4.0/.

\section{References}

Aryal DR, Gómez-González RR, Hernández-Nuriasmú R, Morales-Ruiz DE (2019) Carbon stocks and tree diversity in scattered tree silvopastoral systems in Chiapas. Mexico 
Agroforest Syst 93(1):213-227. https://doi.org/10.1007/ s10457-018-0310-y

Beech E, Rivers M, Rabarimanarivo M, Ravololomanana $\mathrm{N}$, Manjato N, Lantoarisoa F, Andriambololonera S, Ramandimbisoa B, Ralimanana H, Rakotoarisoa SE, Razanajatovo H, Razafiniary V, Andriamanohera A, Randrianasolo V, Rakotonasolo F, Rakotoarisoa A, Randriamamonjy N, Rajaovelona L, Rakotomalala N, Randriamboavonjy T, Rajaonah MT, Rabehevitra D, Ramarosandratana AV, Rakotoarinivo M, Ravaomanalina BH, Jeannoda V (2021) The Red List of Trees of Madagascar. Botanic Gardens Conservation International, Richmond. https://www.researchgate.net/publication/350521569_ The_Red_List_of_Trees_of_Madagascar Accessed 21 April 2021

Callmander MW, Phillipson PB, Schatz GE, Andriambololonera S, Rabarimanarivo M, Rakotonirina N, Raharimampionona J, Chatelain C, Gautier L, Lowry PP (2011) The endemic and non-endemic vascular flora of Madagascar updated. Plant Ecol Evol 144(2):121-125. https://doi.org/ 10.5091/plecevo.2011.513

Chen H (2018) VennDiagram: Generate High-Resolution Venn and Euler Plots. R package version 1.6.20. https:// CRAN.R-project.org/package $=$ VennDiagram

Dufils JM (2003) Remaining forest cover. In: Goodman SM, Benstead JP (eds) The Natural History of Madagascar. University of Chicago Press, Chicago, pp 88-96

ESDAC (2014) Soil Atlas of Africa and its associated Soil Map. European Commission. https://esdac.jrc.ec.europa. eu/content/soil-map-soil-atlas-africa\#tabs-0-descr iption=2 Accessed 20 November 2021

FAO (2015) Agroforestry. Food and Agriculture Organization of the United Nations. http://www.fao.org/forestry/agrof orestry/80338/en/ Accessed 23 March 2021

FAO (2020) FAOSTAT. Food and Agriculture Organization of the United Nations. http://www.fao.org/faostat/en/\#data/ QC Accessed 16 July 2021

Furo G, Manaye A, Negasa A (2020) Identification of spice shade and support tree species, south western Ethiopia. Agroforest Syst 94:95-102. https://doi.org/10.1007/ s10457-019-00372-w

Ganzhorn JU, Lowry PP, Schatz GE, Sommer S (2001) The biodiversity of Madagascar: one of the world's hottest hotspots on its way out. Oryx 35(4):346-348. https://doi.org/ 10.1046/j.1365-3008.2001.00201.x

Ganzhorn JU, Wilmé L, Mercier JL (2014) Explaining Madagascar's Biodiversity. In: Scales IR (ed) Conservation and Environmental Management in Madagascar. Routledge, London, pp 17-43

Gérard A, Ganzhorn JU, Kull CA, Carrière SM (2015) Possible roles of introduced plants for native vertebrate conservation: the case of Madagascar. Restor Ecol 23(6):768-775. https://doi.org/10.1111/rec.12246

GlobalTreeSearch (2021) Botanic Gardens Conservation International. https://tools.bgci.org/global_tree_search.php Accessed 08 April 2021

Gomes ACS, Andrade A, Barretosilva JS, Brenes-Arguedas T, López DC, de Freitas CC, Lang C, de Oliveira AA, Pérez AJ, Perez R, da Silva JB, Silveira AMF, Vaz MC, Vendrami J, Vicentini A (2013) Local plant species delimitation in a highly diverse Amazonian forest: do we all see the same species? J Veg Sci 24(1):70-79. https://doi.org/ 10.1111/j.1654-1103.2012.01441.x

Van der Grijp P (1997) Brown gold: Official expectations and local assessment of the tongan vanilla production. J Soc Ocean 104(1):93-103. https://www.persee.fr/doc/jso_ 0300-953x_1997_num_104_1_2016

Hänke H, Barkmann J, Blum L, Franke Y, Martin DA, Niens J, Osen K, Uruena V, Witherspoon SA, Wurz A (2018) Perspectives on vanilla farming in the SAVA Region (northeastern Madagascar): The Diversity Turn Baseline Study (DTBS). Diskussionsbeitrag No. 1806. Georg-AugustUniversität Göttingen, Department für Agrarökonomie und Rurale Entwicklung (DARE), Göttingen. https:// www.econstor.eu/bitstream/10419/183584/1/1032725907. pdf Accessed 16 July 2021

Hending D, Andrianiaina A, Rakotomalala Z, Cotton S (2018) The use of vanilla plantations by lemurs: encouraging findings for both lemur conservation and sustainable agroforestry in the Sava region, Northeast Madagascar. Int J Primatol 39:141-153. https://doi.org/10.1007/ s10764-018-0022-1

Hernandez J, Lubinsky P (2011) Cultivation Systems. In: Odoux E, Grisoni M (eds) Vanilla: Medicinal and Aromatic Plants - Industrial Profiles. CRC Press, Boca Raton, pp 75-96

Irwin MT, Wright PC, Birkinshaw C, Fisher BL, Gardner CJ, Glos J, Goodman SM, Loiselle P, Rabeson P, Raharison JL, Raherilalao MJ, Rakotondravony D, Raselimanana A, Ratsimbazafy J, Sparks JS, Wilmé L, Ganzhorn JU (2010) Patterns of species change in anthropogenically disturbed forests of Madagascar. Biol Conserv 143:2351-2362. https://doi.org/10.1016/j.biocon.2010. 01.023

IUCN (2021) IUCN Red List of Threatened Species. The International Union for Conservation of Nature https://www. iucnredlist.org/ Accessed 08 April 2021

Jaccard P (1902) Lois de distribution florale. Bull De La Socíeté Vaudoise Des Sci Natur. 38:69-130. https://doi. org/10.5169/seals-266762

Karger DN, Conrad O, Böhner J, Kawohl T, Kreft H, SoriaAuza RW, Zimmermann NE, Linder HP, Kessler M (2017) Climatologies at high resolution for the earth's land surface areas. Sci Data 4:170122. https://doi.org/10. 1038/sdata.2017.122

Kay S, Kühn E, Albrecht M, Sutter L, Szerencsits E, Herzog F (2020) Agroforestry can enhance foraging and nesting resources for pollinators with focus on solitary bees at the landscape scale. Agroforest Syst 94(2):379-387. https:// doi.org/10.1007/s10457-019-00400-9

Komarek AM (2010) Crop diversification decisions: the case of vanilla in Uganda. Q J Int Agric 49(3):227-242. https:// ageconsearch.umn.edu/record/155551 Accessed 17 July 2021

Kull CA, Tassin J, Moreau S, Rakoto Ramiarantsoa H, BlancPamard C, Carrière SM (2012) The introduced flora of Madagascar. Biol Invas. 14(4):875-888. https://doi.org/ 10.1007/s10530-011-0124-6

Kull CA, Carrière SM, Moreau S, Ramiarantsoa HR, BlancPamard C, Tassin J (2013) Melting pots of biodiversity tropical smallholder farm landscapes as guarantors of sustainability. Environ Sci Policy Sustain Dev. 55(2):6-16 
Le Roux DS, Ikin K, Lindenmayer DB, Manning AD, Gibbons P (2015) Single large or several small? applying biogeographic principles to tree-level conservation and biodiversity offsets. Biol Conserv 191:558-566. https://doi.org/10. 1016/j.biocon.2015.08.011

Lemon J (2006) Plotrix: a package in the red light district of R. R-News 6(4): 8-12. https://www.researchgate.net/publi cation/260171541_Plotrix_A_package_in_the_red_light_ district_of_R Accessed 19 July 2021

Liu Z, Jia G, Yu X (2020) Water uptake and WUE of apple tree-corn agroforestry in the loess hilly region of China. Agric Water Manag 234:106138. https://doi.org/10. 1016/j.agwat.2020.106138

Llopis JC, Harimalala PC, Bär R, Heinimann A, Rabemananjara ZH, Zaehringer JG (2019) Effects of protected area establishment and cash crop price dynamics on land use transitions 1990-2017 in north-eastern Madagascar. J Land Use Sci 14(1):52-80. https://doi.org/10.1080/17474 23X.2019.1625979

Mann H, Whitney D (1947) On a test of whether one of two random variables is stochastically larger than the other. Ann Math Stat 18(1):50-60. https://doi.org/10.1214/ aoms/1177730491

Martin DA, Osen K, Grass I, Hölscher D, Tscharntke T, Wurz A, Kreft H (2020) Land-use history determines ecosystem services and conservation value in tropical agroforestry. Conserv Lett 13(5):e12740. https://doi.org/10.1111/conl. 12740

Martin DA, Wurz A, Osen K, Grass I, Hölscher D, Rabemanantsoa T, Tscharntke T, Kreft H (2021a) Shade-tree rehabilitation in vanilla agroforests is yield neutral and may translate into landscape-scale canopy cover gains. Ecosystems 24:1253-1267. https://doi.org/10.1007/ s10021-020-00586-5

Martin DA, Andriafanomezantsoa R, Dröge S, Osen K, Rakotomalala E, Wurz A, Andrianarimisa A, Kreft H (2021b) Bird diversity and endemism along a land-use gradient in Madagascar: the conservation value of vanilla agroforests. Biotropica 53(1):179-190. https://doi.org/10.1111/btp. 12859

Michel I, Lobietti M, Danthu P, Penot E, Velonjara F, Jahiel M, Michels T (2021) Agroforestry innovation by smallholders facing uncertainty: the case of clove-based cropping systems in Madagascar. Eur J Agron 123:126218. https:// doi.org/10.1016/j.eja.2020.126218

Minh VT, Mizuno K, Funakawa S, Shinjo H, Tanaka U (2015) Introduction of vanilla to mountainous villages of central Vietnam. Trop Agr Develop. 59(4):99-206. https://doi. org/10.11248/jsta.59.199

Moat J, Smith P (2007) Atlas of the vegetation of Madagascar. Kew Publishing, Royal Botanical Gardens, Kew, London, Atlas de la Végétation de Madagascar

Montagnini F (2020) The contribution of agroforestry to restoration and conservation: biodiversity islands in degraded landscapes. In: Dagar JC, Gupta SR, Teketay D (eds) Agroforestry for Degraded Landscapes. Springer, Singapore, pp 445-479. https://doi.org/10.1007/978-981-154136-0_15

Myers N, Mittermeier RA, Mittermeier CG, da Fonseca GAB, Kent J (2000) Biodiversity hotspots for conservation priorities. Nature 403:853-858. https://doi.org/10.1038/ 35002501

Nesper M, Kueffer C, Krishnan S, Kushalappa CG, Ghazoul J (2017) Shade tree diversity enhances coffee production and quality in agroforestry systems in the Western Ghats. Agric Ecosyst Environ 247:172-181. https://doi.org/10. 1016/j.agee.2017.06.024

Oksanen J, Blanchet FG, Friendly M, Kindt R, Legendre P, McGlinn D, Minchin PR, O’Hara RB, Simpson GL, Solymos P, Henry M, Stevens H, Szoecs E, Wagner H (2019) vegan: Community Ecology Package. R package version 2.5-6. https://CRAN.R-project.org/package=vegan

OpenStreetMap (2021) https://www.openstreetmap.org/copyr ight Accessed 21 April 2021

Osen K, Soazafy MR, Martin DA, Wurz A, März A, Ranarijaona HLT, Hölscher D (2021) Land-use history determines stand structure and tree diversity in vanilla agroforests of northeastern Madagascar. Appl Veg Sci 24(1):e12563. https://doi.org/10.1111/avsc.12563

R Core Team (2013) R: A language and environment for statistical computing. R Foundation for Statistical Computing, Vienna, Austria. http://www.R-project.org/

Rakotoarinivo M, Dransfield J, Bachman SP, Moat J, Baker WJ (2014) Comprehensive red list assessment reveals exceptionally high extinction risk to madagascar palms. PLoS ONE 9(8):e106619. https://doi.org/10.1371/journal.pone. 0106619

Randrianaivo R (2014) Rapport sur l'inventaire floristique d' "Antanetiambo Nature Reserve". Missouri Botanical Garden.

Raveloaritiana E, Wurz A, Grass I, Osen K, Soazafy MR, Martin DA, Faliniaina L, Rakotomalala NH, Vorontsova MS, Tscharntke T, Rakouth B (2021) Land-use intensification increases richness of native and exotic herbaceous plants, but not endemics Malagasy vanilla landscapes. Divers Distrib 27(5):784-798. https://doi.org/10.1111/ddi.13226

Schatz GE (2001) Generic tree flora of Madagascar. Royal Botanic Gardens, Kew

Schroth G, da Fonseca GAB, Harvey CA, Gascon C, Vasconcelos HL, Izac AMN, Angelsen A, Finegan B, Kaimowitz D, Krauss U, Laurance SGW, Laurance WF, Nasi R, Naughton-Treves L, Niesten E, Richardson DM, Somarriba E, Tucker NIJ, Vincent G, Wilkie DS (2004) Conclusion: Agroforestry and Biodiversity Conservation in Tropical Landscapes. In: Schroth G, da Fonseca GAB, Harvey CA, Gascon C, Vasconcelos HL, Izac AMN (eds) Agroforestry and Biodiversity Conservation in Tropical Landscapes. Island Press, Washington, Covelo, London, pp 487-501. https://www.researchgate.net/profile/CeliaHarvey/publication/40777441_Agroforestry_and_Biodi versity_Conservation_in_Tropical_Landscapes/links/ 5e42cb79a6fdccd9659a5af7/Agroforestry-and-Biodiversi ty-Conservation-in-Tropical-Landscapes.pdf\#page $=500$ Accessed 12 March 2021

Schwab D, Wurz A, Grass I, Rakotomalala AANA, Osen K, Soazafy MR, Martin DA, Tscharntke T (2021) Decreasing predation rates and shifting predator compositions along a land-use gradient in Madagascar's vanilla landscapes. J Appl Ecol 58(2):360-371. https://doi.org/10.1111/13652664.13766 
Shannon CE (1949) Communication theory of secrecy systems. Bell Syst Tech J 28(4):656-715. https://doi.org/10. 1002/j.1538-7305.1949.tb00928.x

Shapiro SS, Wilk MB (1965) An analysis of variance test for normality (complete samples). Biometrika 52(3/4):591611. https://doi.org/10.2307/2333709

Torppa KA, Wirta H, Hanski I (2020) Unexpectedly diverse forest dung beetle communities in degraded rain forest landscapes in Madagascar. Biotropica 52(2):351-365. https://doi.org/10.1111/btp.12767

Tropicos (2021) Catalogue of the Plants of Madagascar. http:// legacy.tropicos.org/Project/Madagascar Accessed 08 April 2021

Tscharntke T, Clough Y, Bhagwat S, Buchori D, Faust H, Hertel D, Hölscher D, Juhrbandt J, Kessler M, Perfecto Y, Schroth G, Veldkamp E, Wanger T (2011) Multifunctional shade-tree management in tropical agroforestry landscapes - a review. J Appl Ecol 48:619-629. https://doi. org/10.1111/j.1365-2664.2010.01939.x

Vieilledent G, Grinand C, Rakotomalala FA, Ranaivosoa R, Rakotoarijaona JR, Allnutt TF, Achard F (2018) Combining global tree cover loss data with historical national forest cover maps to look at six decades of deforestation and forest fragmentation in Madagascar. Biol Conserv 222:189-197. https://doi.org/10.1016/j.biocon.2018.04. 008
Welch BL (1947) The generalization of "student's" problem when several different population variances are involved. Biometrika 34(1/2):28-35. https://doi.org/10.2307/23325 10

World Agroforestry Centre (2009) Agroforestree database. http://apps.worldagroforestry.org/treedb/index.php June 2021)

Wu J, Liu W, Chen C (2016) Can intercropping with the world's three major beverage plants help improve the water use of rubber trees? J Appl Ecol 53(6):1787-1799. https://doi.org/10.1111/1365-2664.12730

Yesuf G, Brown KA, Walford N (2019) Assessing regionalscale variability in deforestation and forest degradation rates in a tropical biodiversity hotspot. Remote Sens Ecol Conserv 5(4):346-359. https://doi.org/10.1002/rse2.110

Zaehringer JG, Eckert S, Messerli P (2015) Revealing regional deforestation dynamics in north-eastern Madagascar insights from multi-temporal land cover change analysis. Land 4:454-474. https://doi.org/10.3390/land4020454

Publisher's Note Springer Nature remains neutral with regard to jurisdictional claims in published maps and institutional affiliations. 